\title{
PREFÁCIO
}

\section{Impactos do distanciamento social sobre a percepção da realidade}

Olá! O volume 12, número 2 da revista Projética traz doze artigos originais, sendo quatro na seção Design para Sustentabilidade, um na seção Design: Conhecimento, Gestão e Tecnologia, um na seção Ergonomia e Usabilidade, três na seção Design: Educação, Cultura e Sociedade, e três na seção Design de Moda. Por sua vez, a Profa. Dra. Camila Santos Doubek Lopes, editora da seção Design para Sustentabilidade, assina o editorial da edição, e de maneira muito instigante convida o leitor a explorar os trabalhos completos!

Seguindo com a sequência iniciada da edição anterior, a capa da vez também foi extraída do projeto interdisciplinar realizado com estudantes do curso de graduação em Design Gráfico, cujo foco foi o desenvolvimento de Manifestos sobre Design e Cultura no contexto da pandemia de COVID-19. Esta capa, idealizada e produzida por Ian Gabella Pintos e Manuela Hata Aulicino, ambos estudantes da terceira série, nos leva a refletir sobre o atual momento que vivemos.

A composição foi criada no contexto de pandemia, na qual nossa realidade foi distorcida. Para representar isso, foi utilizado a foto de um recipiente de vidro sobreposta a foto de fundo, que espelha o contato humano. O vidro, com seus reflexos, altera a imagem do toque entre as mãos e simboliza o modo que o distanciamento social nos impacta. A foto do vidro foi editada para que ficasse com grande contraste, ressaltando os brilhos da composição e, assim, foi possível aplicá-la no fundo com um modo de mesclagem que deixou visíveis somente as partes mais claras dessa imagem. Ela também recebeu um tratamento de cor para ressaltar o azul, trazendo assim uma ideia de solidão. 
Além disso, destacamos mais uma alteração ocorrida em nosso comitê editorial. A seção Ergonomia e Usabilidade, antes sob a responsabilidade da Profa. Dra. Vanessa Tavares de Oliveira Barros, passa a cargo da Profa. Dra. Cristiane Affonso de Almeida Zerbetto. Damos as boas-vindas à Profa. Cristiane, e registramos nossos sinceros agradecimentos à Profa. Vanessa, com a certeza de que seu brilhante legado será continuado! Também agradecemos a todos e todas que se envolveram com os processos de produção deste número, sem o esforço dos quais a publicação não seria possível, e aos nossos leitores e leitoras. Abraços e boa leitura!

Me. Murilo Crivellari Camargo Editor de Seção Ian Gabella Pintos \& Manuela Hata Aulicino Designers convidados

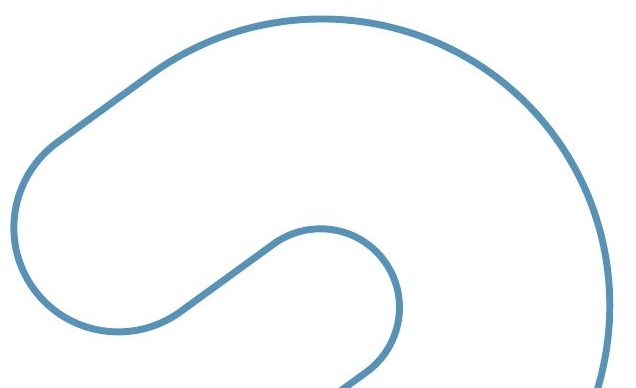

